\title{
The lumbosacral plexus of the red-rumped agouti (Dasyprocta leporina Linnaeus, 1758) (Rodentia: Caviidae)
}

\section{Plexo lombossacral da cutia (Dasyprocta leporina Linnaeus, 1758) (Rodentia: Caviidae)}

\author{
Gleidson Benevides de Oliveira' ${ }^{1 *}$; Hélio Noberto de Araújo Júnior ${ }^{2}$; \\ Paulo Mateus Alves Lopes²; Herson da Silva Costa ${ }^{3}$; Radan Elvis Matias de Oliveira ${ }^{3}$; \\ Carlos Eduardo Bezerra de Moura ${ }^{4}$; Valéria Veras de Paula ${ }^{4}$; Moacir Franco de Oliveira ${ }^{4}$
}

\begin{abstract}
The red-rumped agouti, a small, wild rodent belonging to the Dasyproctidae family, has great zootechnical potential and adapts well to captivity. In order to contribute to the knowledge regarding the neuroanatomy of the species, the aim of this study was to describe the origin of the nerves forming the lumbosacral plexus by evaluating 12 animals (six males and six females) that had been used in previous experiments. Animals were fixed in a $10 \%$ aqueous formaldehyde solution and eviscerated after 72 hours. Major and minor psoas muscles were then retracted to expose the nerves forming the plexus, and the plexus was bleached via cotton soaked in 20 -volume hydrogen peroxide for 12 hours for subsequent dissection. Topographical relations of the lumbosacral plexus were grouped into tables and arranged in terms of simple percentages. In seven cases (58.34\%), the lumbosacral plexus in the red-rumped agouti stemmed from the ventral roots of the last four lumbar nerves and the first three sacral nerves (Type I: $\mathrm{L}_{4}-\mathrm{S}_{3}$ ). In four animals $\left(33.33 \%\right.$ ), the lumbosacral plexus stemmed from $\mathrm{L}_{5}-\mathrm{S}_{3}$ (Type II), and in one case $(8.33 \%)$ it stemmed from $\mathrm{L}_{5}-\mathrm{S}_{4}$ (Type III). Together, our observations demonstrated that the lumbosacral plexus of the red-rumped agouti comprised the lateral femoral cutaneous, genitofemoral, femoral, obturator, sciatic, cranial gluteal, caudal gluteal, and pudendal nerves. Finally, the origin of the lumbosacral plexus and its constituent spinal nerves was similar to what has been described in other rodents, including the rock cavy, lowland paca, and Spix's yellow-toothed cavy.
\end{abstract}

Key words: Anatomy. Dasyprocta leporine. Nerves. Nervous system. Rodent.

\section{Resumo}

A cutia é um roedor silvestre, de pequeno porte pertencente à família Dasyproctidae, com grande potencial zootécnico e que se adapta bem ao cativeiro. De forma a contribuir acerca da biologia da espécie, objetivou-se descrever a origem dos nervos que formam o plexo lombossacral. Foram utilizados 12 animais (6 machos e 6 fêmeas), provenientes de experimentos anteriores. Os animais foram fixados em solução aquosa de formaldeído a $10 \%$ e após 72 horas, eviscerados. Em seguida os músculos psoas maior e menor foram rebatidos, expondo-se os nervos que formavam o plexo. Sobre estes nervos foi

${ }^{1}$ Discente de Doutorado em Ciência Animal, Universidade Federal Rural do Semi-Árido, UFERSA, Mossoró, RN, Brasil. E-mail: Brasil. E-mail: gleidson_benevides@hotmail.com

2 Discentes do Curso de Medicina Veterinária, UFERSA, Mossoró, RN, Brasil. E-mail: helio.noberto@outlook.com; paulomateusalveslopes@hotmail.com

3 Discentes de Mestrado em Ciência Animal, UFERSA, Mossoró, RN, Brasil. E-mail: herson-costa@hotmail.com; radan_elvis@ hotmail.com

${ }^{4}$ Profs., UFERSA, Mossoró, RN, Brasil. E-mail: carlos.moura@ufersa.edu.br; valeria@ufersa.edu.br; moacir@ufersa.edu.br

* Author for correspondence 
colocado algodão embebido com peróxido de hidrogênio a 20 volumes, permanecendo por 12 horas seguidas para clareamento e consequente dissecação. As relações topográficas do plexo lombossacral agrupadas em tabelas em forma de porcentagem simples. O plexo lombossacral da cutia originou-se em sete casos $(58,34 \%)$ a partir das raízes ventrais dos quatro últimos nervos lombares e três primeiros nervos sacrais (Tipo I - $\mathrm{L}_{4}-\mathrm{S}_{3}$ ), em quatro animais $\left(33,33 \%\right.$ ) a partir de $\mathrm{L}_{5}-\mathrm{S}_{3}$ (Tipo II) e um caso $(8,33 \%$ ) a partir de $\mathrm{L}_{5}-\mathrm{S}_{4}$ (Tipo III). Os nervos que participaram do plexo lombossacral da cutia foram: cutâneo femoral lateral, genitofemoral, femoral, obturatório, isquiático, glúteo cranial, glúteo caudal e nervo pudendo. A origem do plexo lombossacral e os nervos espinhais constituintes deste plexo em cutias foram semelhantes ao descrito em alguns roedores como mocó, paca e preá.

Palavras-chave: Anatomia. Dasyprocta leporina. Nervos. Roedor. Sistema nervoso.

\section{Introduction}

The red-rumped agouti is a small, wild rodent belonging to the Dasyproctidae family, whose members are predominantly active at dawn and dusk. The rodent has diverse eating habits and inhabits rain forest and semi-deciduous forest areas, as well as the Cerrado and Caatinga regions. The Dasyprocta leporina species is particularly distributed throughout Brazil, and has been observed from the state of Pará to the southern states of Brazil (MOOJEN, 1952).

Red-rumped agoutis are cited as a major source of animal protein for rural populations in the tropics (KLEIMAN et al., 1979), and Brazil has facilities that are authorized for breeding these rodents for commercial purposes (MOCKRIN et al., 2005). In addition to the livestock potential of this species, it is also noteworthy that red-rumped agoutis can be used as potential experimental models, contributing to the development of significant research for both human beings and the animal species as a whole (MOCKRIN et al., 2005).

Veterinary anatomy treatises (DYCE et al., 2004; KÖNIG; LIEBICH, 2011) describe that the lumbosacral plexus stems from the union of nerves making up the lumbar plexus (Plexus lumbalis) and those making up the sacral plexus (Plexus sacralis), which usually consist of the ventral nerve branches of the last four lumbar vertebrae and the first sacral vertebrae. These nerves are responsible for innervating the pelvic limbs, lumbar and sacral regions, and viscera in this region. In this regard, the study of these nerves is of great importance due to the many diseases that are likely to affect them; injury to these nerves can impair locomotion, leading to paresis or paralysis in the pelvic limbs and tail. Furthermore, knowledge of the topography of the lumbosacral plexus is valuable for applying epidural anesthesia, a technique widely used in obstetric procedures; this knowledge also aids in clinical and surgical rectal interventions and some orthopedic surgeries (MASSONE, 2011).

Several papers have described the nerves that make up the lumbosacral plexus in the chinchilla (PEREIRA; RICKES, 2011; RONDINI et al., 2005), rock cavy (LACERDA et al., 2006; OLIVEIRA et al., 2011; SANTOS et al., 2006), porcupine (AYDIN et al., 2009), red squirrel (AYDIN, 2010), Spix's yellow-toothed cavy (OLIVEIRA et al., 2010, 2014), lowland paca (TONINI et al., 2014), ocelot (LOPES et al., 2012), and anteater (CARDOSO et al., 2013; CRUZ et al., 2014); however, to date, there is no description of the union of nerves that make up the lumbosacral plexus of the red-rumped agouti.

Finally, it should be noted that data related to nerves derived from the lumbosacral plexus provide not only knowledge that is indispensable for comparative anatomy, but also for those using the red-rumped agouti in laboratory research. Thus, we decided to conduct this study in consideration of the clinical significance of the lumbosacral plexus, the zootechnical potential of the red-rumped agouti, and the fact that such species-specific information is not currently available in the literature. 


\section{Materials and Methods}

In order to conduct this research, we investigated 12 red-rumped agoutis (six males and six females) that had been employed in previous experiments (stored in a freezer). This study was approved by the Institutional Bioethics Committee (Opinion CEUA/UFERSA 15/2014, under the Process 23091.000653/2014-26) at the Center for Multiplication of Wild Animals (CEMAS/ UFERSA). The animals were fixed in a $10 \%$ formaldehyde solution and dissected after 72 hours. Dissections involved opening of the abdominal cavity by means of a pre-retroumbilical median longitudinal incision. Later, the skin, subcutaneous tissue, and viscera were removed.

To identify nerve roots in the lumbosacral plexus along the lateral intervertebral or vertebral foramina, major and minor psoas muscles were removed to expose the plexus. Cotton soaked with 20 -volume hydrogen peroxide was then placed on the plexus for 12 hours to ensure bleaching and better visualization of the plexus nerves.

When needed, a 10× magnifying glass (Zeiss) was used; however, the majority of these dissections were done without magnification. Our findings are presented as schematic drawings and photographs, and data are expressed in tables and arranged as simple percentages. The nomenclature used in this paper is based on the Veterinary Anatomical Nomenclature (INTERNATIONAL COMMITTEE ON VETERINARY GROSS ANATOMICAL NOMENCLATURE, 2012).

\section{Results}

We found that all animals had seven lumbar, four sacral, and six coccygeal vertebrae. Through skeletopic results of the red-rumped agouti, we were able to classify the origin of the lumbosacral plexus into three types (type $\mathrm{I}$ : $\mathrm{L}_{4}-\mathrm{S}_{3}$; type II: $\mathrm{L}_{5}-\mathrm{S}_{3}$; type III: $\mathrm{L}_{5}-\mathrm{S}_{4}$ ) (Figures $1,2,3$ ), with type I appearing most often (observed in seven animals; 58.34\%), and types II and III appearing at a frequency of $33.33 \%$ and $8.33 \%$, respectively (Table 1).

The lumbosacral plexus in the red-rumped agouti comprised the following nerves: lateral femoral cutaneous, genitofemoral, femoral, obturator, sciatic, cranial gluteal, caudal gluteal, and pudendal nerves. Table 2 represents the origin and frequency of each nerve, arranged in the right and left antimeres.

The lateral femoral cutaneous nerve in the redrumped agouti stemmed more frequently $(50.00 \%)$ from the $\mathrm{L}_{4} \mathrm{~L}_{5}$ and less frequently from $\mathrm{L}_{4}(8.33 \%)$, $\mathrm{L}_{5} \mathrm{~L}_{6}(8.33 \%)$, or only of roots from the $\mathrm{L}_{5}(33.34 \%)$. In seven animals (58.33\%), the genitofemoral nerve stemmed from the ventral branches of the fourth and fifth lumbar nerves, in four animals (33.34\%) from $\mathrm{L}_{5}$, and in one animal $(8.33 \%)$ from $\mathrm{L}_{5} \mathrm{~L}_{6}$. In five animals $(41.67 \%)$, the femoral nerve stemmed more frequently from $\mathrm{L}_{5}-\mathrm{L}_{7}$, while in four animals $(33.34 \%)$ it stemmed from $\mathrm{L}_{5} \mathrm{~L}_{6}$, and in two specimens $(16.66 \%)$ from $\mathrm{L}_{6} \mathrm{~L}_{7}$; there was also a small contribution by $\mathrm{L}_{4}$ in the right antimere of one animal in this study $(8.33 \%)$. The obturator nerve was observed in seven animals $(58.33 \%)$ from $\mathrm{L}_{5}-$ $\mathrm{L}_{7}$ and in two (16.67\%) and three (25\%) animals from $\mathrm{L}_{5} \mathrm{~L}_{6}$ and $\mathrm{L}_{6} \mathrm{~L}_{7}$, respectively. The sciatic nerve stemmed more frequently $(58.34 \%)$ from the ventral rami coming from $\mathrm{L}_{7}-\mathrm{S}_{2}$, with few animals demonstrating contributions from the sixth lumbar $(33.33 \%)$ or third sacral $(8.33 \%)$ nerves. In turn, in six animals $(50 \%)$ the cranial gluteal nerve was formed by nerve branches from $\mathrm{L}_{7}$, in four $(33.33 \%)$ from $\mathrm{L}_{7}-\mathrm{S}_{1}$ and in two (16.67\%) from $\mathrm{S}_{1}$. In 10 animals (83.34\%), the caudal gluteal nerve stemmed from $\mathrm{S}_{1}$, while in one animal $(8.33 \%)$ it stemmed from $S_{1} S_{2}$ and in the other animal from $S_{2}(8.33 \%)$. In seven specimens $(58.33 \%)$, the pudendal nerve was formed by the ventral nerve roots from $\mathrm{S}_{2} \mathrm{~S}_{3}$, in three animals $(25.00 \%)$ from $\mathrm{S}_{3}$ and in two animals $(16.67 \%)$ from $\mathrm{S}_{3} \mathrm{~S}_{4}$. 
Figure 1. Origin of the lumbosacral plexus in the red-rumped agouti in the ventral roots from $\mathrm{L}_{4}-\mathrm{S}_{3}$ (Type I). The lateral femoral cutaneous (a), genitofemoral (b), femoral (c), obturator (d), cranial gluteal (e), caudal gluteal (f), sciatic (g), and pudendal (h) nerves can be observed in A, photomacrograph and B, schematic drawing.

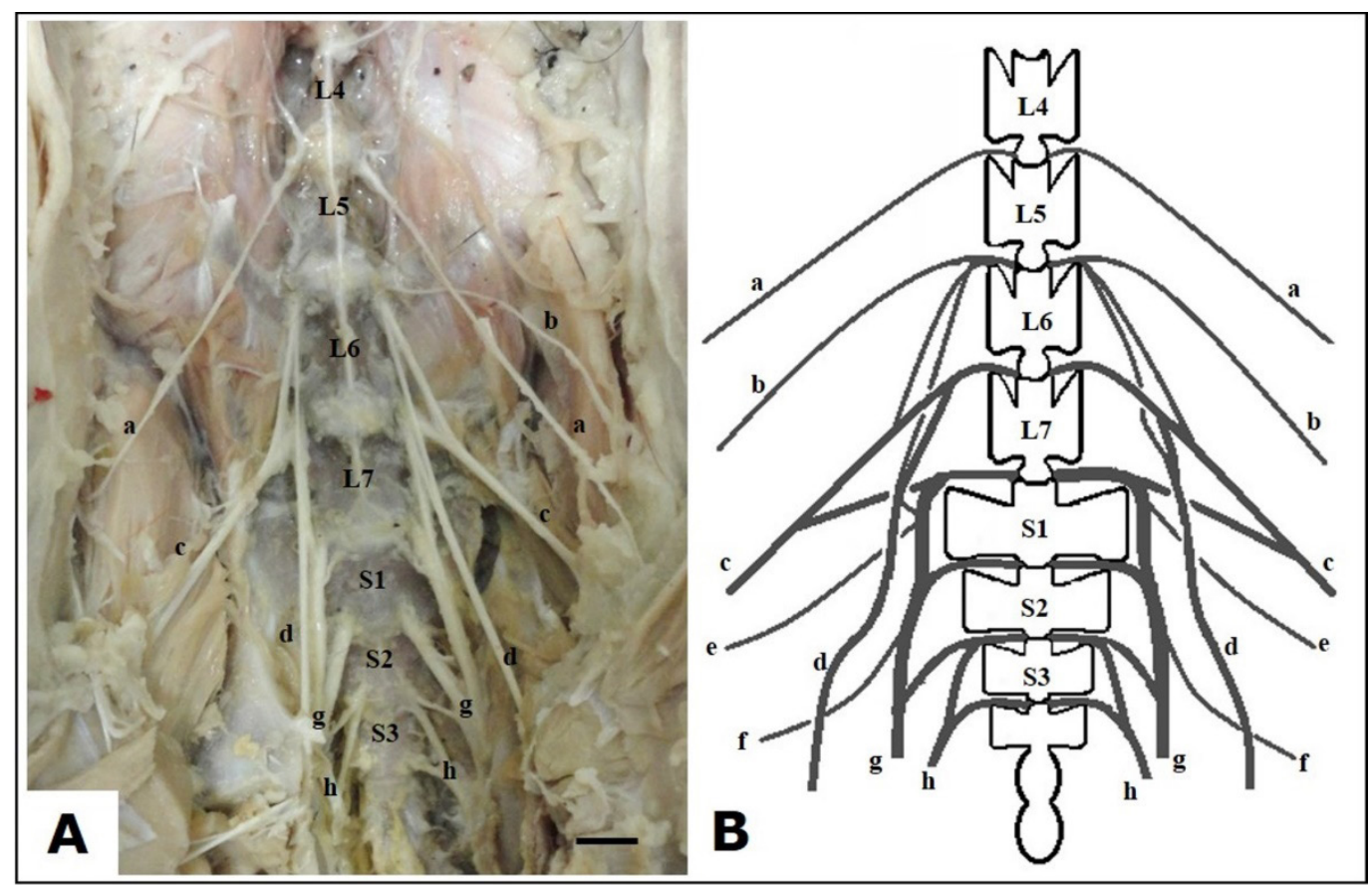

Figure 2. Origin of the lumbosacral plexus in the red-rumped agouti in the ventral roots from $\mathrm{L}_{5}-\mathrm{S}_{3}$ (Type II). The lateral femoral cutaneous (a) genitofemoral (b), femoral (c), obturator (d), cranial gluteal (e), caudal gluteal (f), sciatic (g), and pudendal (h) nerves can be observed in A, photomacrograph and B, schematic drawing.

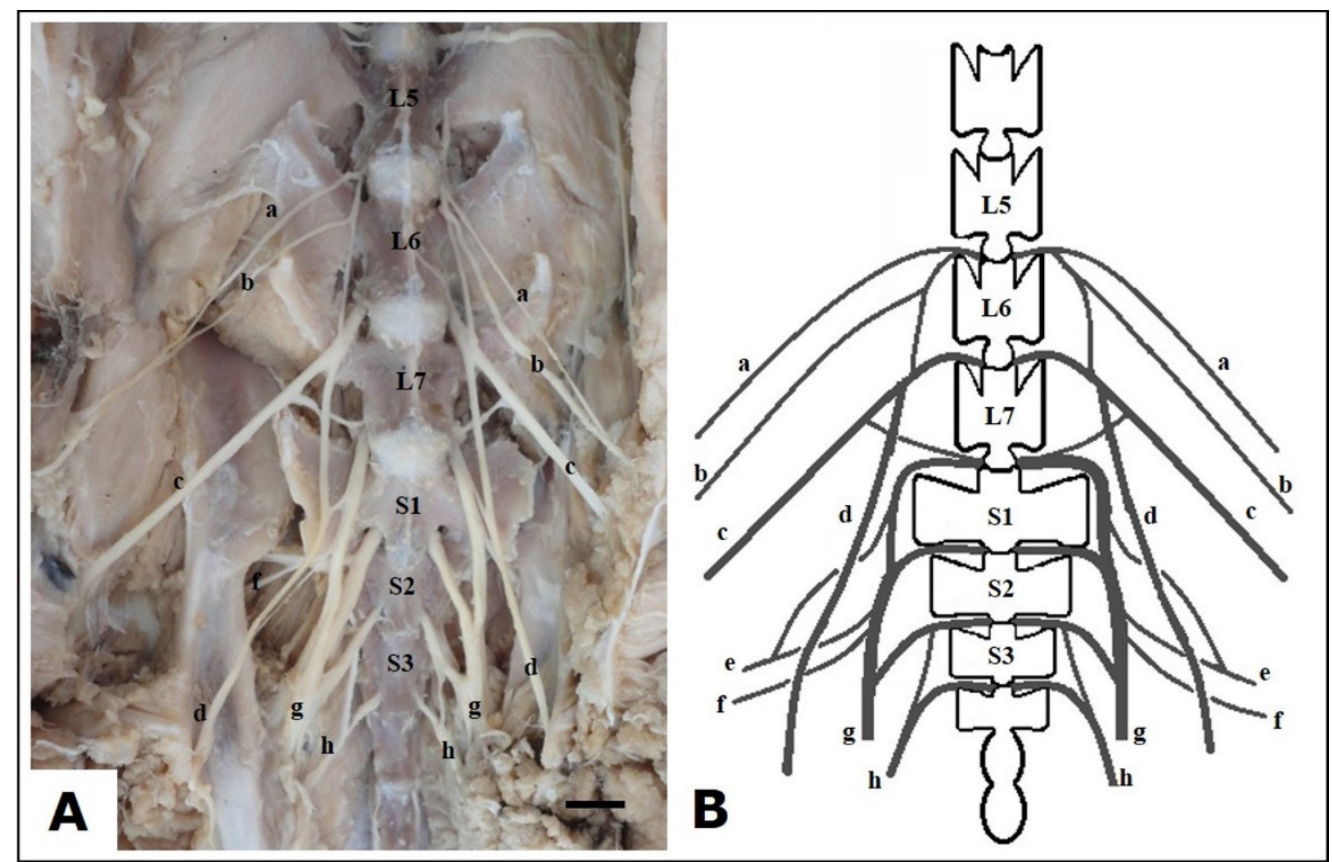


Figure 3. Origin of the lumbosacral plexus in the red-rumped agouti in the ventral roots from $\mathrm{L}_{5}-\mathrm{S}_{4}$ (Type III). The lateral femoral cutaneous (a) genitofemoral (b), femoral (c), obturator (d), cranial gluteal (e), caudal gluteal (f), sciatic $(\mathrm{g})$, and pudendal $(\mathrm{h})$ nerves can be observed in A, photomacrograph and $\mathrm{B}$, schematic drawing.

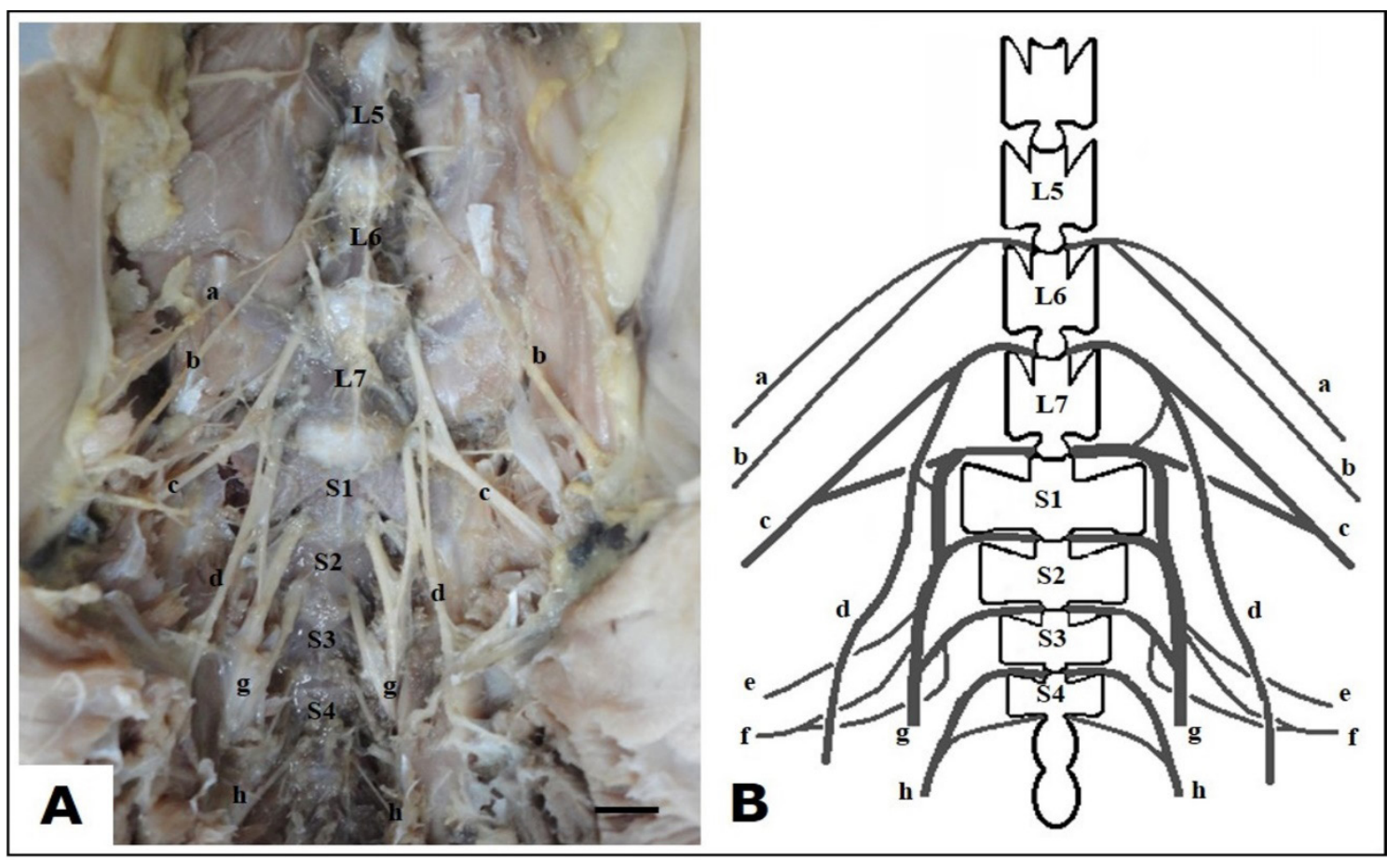

Table 1. Origin of the lumbosacral plexus in the red-rumped agouti.

\begin{tabular}{lcccc}
\hline \multirow{2}{*}{ Origin } & \multicolumn{2}{c}{ Absolute frequency } & \multicolumn{2}{c}{ Frequency (\%) } \\
\cline { 2 - 5 } & RA & LA & RA & LA \\
\hline Type I $\left(\mathrm{L}_{4}-\mathrm{S}_{3}\right)$ & 7 & 7 & 58.34 & 58.34 \\
Type II $\left(\mathrm{L}_{5}-\mathrm{S}_{3}\right)$ & 4 & 4 & 33.33 & 33.33 \\
Type III $\left(\mathrm{L}_{5}-\mathrm{S}_{4}\right)$ & 1 & 1 & 8.33 & 8.33 \\
Total & 12 & 12 & 100 & 100 \\
\hline
\end{tabular}

Table 2. Origin and frequency of nerves making up the lumbosacral plexus in the common agouti in the right antimere (RA) and left antimere (LA).

\begin{tabular}{ccccccc}
\hline \multirow{2}{*}{ Nerves } & \multicolumn{2}{c}{ Origin } & \multicolumn{2}{c}{ Frequency } & \multicolumn{2}{c}{ Continue ... } \\
\cline { 2 - 7 } & RA & LA & RA & LA & RA & LA \\
\hline \multirow{3}{*}{ Lateral femoral cutaneous } & $\mathrm{L}_{4}$ & $\mathrm{~L}_{4}$ & 1 & 1 & 8.33 & 8.33 \\
& $\mathrm{~L}_{4} \mathrm{~L}_{5}$ & $\mathrm{~L}_{4} \mathrm{~L}_{5}$ & 6 & 6 & 50.00 & 50.00 \\
& $\mathrm{~L}_{5}$ & $\mathrm{~L}_{5}$ & 4 & 4 & 33.34 & 33.34 \\
& $\mathrm{~L}_{5} \mathrm{~L}_{6}$ & $\mathrm{~L}_{5} \mathrm{~L}_{6}$ & 1 & 1 & 8.33 & 8.33 \\
& $\mathrm{~L}_{4} \mathrm{~L}_{5}$ & $\mathrm{~L}_{4} \mathrm{~L}_{5}$ & 7 & 7 & 58.33 & 58.33 \\
Genitofemoral & $\mathrm{L}_{5}$ & $\mathrm{~L}_{5}$ & 4 & 4 & 33.34 & 38.34 \\
& $\mathrm{~L}_{5} \mathrm{~L}_{6}$ & $\mathrm{~L}_{5} \mathrm{~L}_{6}$ & 1 & 1 & 8.33 & 8.33 \\
\hline
\end{tabular}




\begin{tabular}{|c|c|c|c|c|c|c|}
\hline & & & & & & ... Continuation \\
\hline \multirow{4}{*}{ Femoral } & $\mathrm{L}_{4}-\mathrm{L}_{6}$ & $\mathrm{~L}_{4}-\mathrm{L}_{6}$ & 1 & 0 & 8.33 & 0.00 \\
\hline & $\mathrm{L}_{5}^{4} \mathrm{~L}_{6}{ }^{6}$ & $\mathrm{~L}_{5}^{4} \mathrm{~L}_{6}^{6}$ & 4 & 5 & 33.33 & 41.67 \\
\hline & $\mathrm{L}_{6}^{5} \mathrm{~L}_{7}^{6}$ & $\mathrm{~L}_{6}^{5} \mathrm{~L}_{7}^{6}$ & 2 & 2 & 16.66 & 16.66 \\
\hline & $\mathrm{L}_{5}^{0}-\mathrm{L}_{7}$ & $\mathrm{~L}_{5}-\mathrm{L}_{7}$ & 5 & 5 & 41.67 & 41.67 \\
\hline \multirow{3}{*}{ Obturator } & $\mathrm{L}_{5} \mathrm{~L}_{6}$ & $\mathrm{~L}_{5} \mathrm{~L}_{6}$ & 2 & 2 & 16.67 & 16.67 \\
\hline & $\mathrm{L}_{6}^{3} \mathrm{~L}_{7}^{6}$ & $\mathrm{~L}_{6}^{5} \mathrm{~L}_{7}^{6}$ & 3 & 3 & 25.00 & 25.00 \\
\hline & $\mathrm{L}_{5}^{0}-\mathrm{L}_{7}$ & $\mathrm{~L}_{5}-\mathrm{L}_{7}$ & 7 & 7 & 58.33 & 58.33 \\
\hline \multirow{3}{*}{ Sciatic } & $\mathrm{L}_{6}-\mathrm{S}_{2}$ & $\mathrm{~L}_{6}-\mathrm{S}_{2}$ & 4 & 4 & 33.33 & 33.33 \\
\hline & $\mathrm{L}_{7}^{0}-\mathrm{S}_{2}^{2}$ & $\mathrm{~L}_{7}^{0}-\mathrm{S}_{2}^{2}$ & 7 & 7 & 58.34 & 58.34 \\
\hline & $\mathrm{L}_{7}-\mathrm{S}_{3}^{2}$ & $\mathrm{~L}_{7}-\mathrm{S}_{3}$ & 1 & 1 & 8.33 & 8.33 \\
\hline \multirow{3}{*}{ Cranial gluteal } & $\mathrm{L}_{7}$ & $\mathrm{~L}_{7}$ & 6 & 6 & 50.00 & 50.00 \\
\hline & $\mathrm{L}_{7}-\mathrm{S}_{1}$ & $\mathrm{~L}_{7}-\mathrm{S}_{1}$ & 4 & 4 & 33.33 & 33.33 \\
\hline & $\mathrm{S}_{1}$ & $\mathrm{~S}_{1}$ & 2 & 2 & 16.67 & 16.67 \\
\hline \multirow{3}{*}{ Caudal gluteal } & $\mathrm{S}_{1}$ & $\mathrm{~S}_{1}$ & 10 & 10 & 83.34 & 83.34 \\
\hline & $\mathrm{S}_{1} \mathrm{~S}_{2}$ & $\mathrm{~S}_{1} \mathrm{~S}_{2}$ & 1 & 1 & 8.33 & 8.33 \\
\hline & $\mathrm{S}_{2}$ & $\mathrm{~S}_{2}$ & 1 & 1 & 8.33 & 8.33 \\
\hline \multirow{3}{*}{ Pudendal } & $\mathrm{S}_{2} \mathrm{~S}_{3}$ & $\mathrm{~S}_{2} \mathrm{~S}_{3}$ & 7 & 7 & 58.33 & 58.33 \\
\hline & $\mathrm{S}_{3}$ & $\mathrm{~S}_{3}{ }^{3}$ & 3 & 3 & 25.00 & 25.00 \\
\hline & $\mathrm{S}_{3} \stackrel{3}{S}_{4}$ & $\mathrm{~S}_{3} \stackrel{3}{4}_{4}$ & 2 & 2 & 16.67 & 16.67 \\
\hline
\end{tabular}

\section{Discussion}

The lumbosacral plexus is arranged between the lumbar and sacral regions of the axial skeleton in animals, and corresponds to a set of nerve elements that can innervate structures such as the pelvic limbs, tail, and other structures. The plexus is prone to lesions, and is an anatomical component that is significant when considering epidural anesthesia, during obstetric procedures, clinical and surgical rectal interventions, and even orthopedic surgeries (FANTONI; CORTOPASSI, 2009; DYCE et al., 2004; MASSONE, 2011). In red-rumped agoutis, we observed that while formation of the lumbosacral plexus was variable, it was most frequently made up of branches from the four last lumbar nerves and the first three sacral nerves. This arrangement was also observed by Tonini et al. (2014) when describing the lumbosacral plexus in the lowland pacas.

Rodents, which fall into a phylogenetic group that usually exhibits considerable variability in morphological patterns, display differences in the origin of the nerves whose branches make up the lumbosacral plexus. For example, Lacerda et al. (2006) reported this variability when investigating rock cavies and Oliveira et al. (2014) confirmed the same in an experiment on the wild Spix's yellowtoothed cavy. Our findings on the plexus of the redrumped agouti support these reports; specifically, they indicate that the lumbosacral plexus could be represented by branches of the last three lumbar nerves and the first three sacral nerves (or by having contributions from $\mathrm{S}_{4}$ ).

Often, the composition of the lumbosacral plexus varies depending on the number of vertebral elements that make up the lumbar and sacral regions. This variability is very common, and has been described and observed by Lacerda et al. (2006) and Santos et al. (2006) studies addressing rock cavies, where the existence of six or seven lumbar vertebrae was found. Interestingly, our current report revealed that the number of lumbar and sacral vertebrae in red-rumped agoutis did not vary, and that the different plexus arrangements simply resulted from the origin of nerve branches stemming from $\mathrm{L}_{4}-\mathrm{S}_{3}$, $\mathrm{L}_{5}-\mathrm{S}_{3}$, and less frequently $\mathrm{L}_{5}-\mathrm{S}_{4}$. Oliveira et al. (2014), when describing the lumbosacral plexus in wild Spix's yellow-toothed cavy, reported that the number of lumbar and sacral vertebrae does not 
vary, and this plexus stems from nerve branches on $\mathrm{L}_{4}-\mathrm{S}_{3}, \mathrm{~L}_{5}-\mathrm{S}_{2}$, or $\mathrm{L}_{6}-\mathrm{S}_{3}$. It is noteworthy that in the red-rumped agouti the pattern $\mathrm{L}_{4}-\mathrm{S}_{3}$ showed up as the most frequent, while the patterns $\mathrm{L}_{5}-\mathrm{S}_{2}$ and $\mathrm{L}_{6}-$ $\mathrm{S}_{3}$, have not been observed, differing from what has been reported for Spix's yellow-toothed cavy.

In 2010, Aydin described the origin of the lumbosacral plexus in the red squirrel (Sciurus vulgaris) as being derived from $\mathrm{L}_{6}-\mathrm{S}_{2}$, with possible contributions from the fourth and fifth lumbar nerves. These results differ from what we observed in the red-rumped agouti. Alternatively, Pereira and Rickes (2011) addressed the formation of this plexus in chinchillas and identified that it occurs from $\mathrm{L}_{4}-\mathrm{L}_{6}$ and $\mathrm{S}_{1}-\mathrm{S}_{3}$. Additionally, Cooper and Schiller (1975) reported that the lumbosacral plexus in guinea pigs is formed from $\mathrm{L}_{3}-\mathrm{L}_{6}$ and $\mathrm{S}_{1}-\mathrm{S}_{3}$. Thus, it may be inferred that, while the origin of the lumbosacral plexus in the red squirrel differs from the findings reported here for red-rumped agoutis, the origin of the plexus in chinchillas and guinea pigs is closer to our results. It should be noted that although $\mathrm{L}_{3}$ was not found to be involved in the plexus of the red-rumped agouti, we suspect that this difference may be associated with the presence of the seventh lumbar vertebra, whose nerve branches contributed to the plexus origin.

In rats, it has been reported that the plexus originates from $\mathrm{T}_{13}-\mathrm{L}_{6}$ and $\mathrm{S}_{1}-\mathrm{S}_{2}$ (GREENE, 1963), and in the porcupine (AYDIN et al., 2009) from $\mathrm{T}_{15}-\mathrm{L}_{4}$ and $\mathrm{S}_{1} \mathrm{~S}_{2}$. These results suggest that the plexus has a different formation in the redrumped agouti. Such variations may be linked to the morphological differences that separate Old and New World rodents, which arose over the course of evolution due to necessary adaptive changes (e.g., alterations in eating habits). The origin of this plexus has also been reported in other mammals. For example, the plexus originates from $\mathrm{L}_{4} \mathrm{~L}_{5}-\mathrm{S}_{1} \mathrm{~S}_{2}$ in the ocelot (LOPES et al., 2012), $\mathrm{T}_{18}-\mathrm{L}_{3}$ and $\mathrm{S}_{1}-\mathrm{S}_{5}$ in the collared anteater (CARDOSO et al., 2013), $\mathrm{L}_{1}$ to $\mathrm{S}_{3}$ in the fur seal (CASTRO et al., 2009), $\mathrm{L}_{3}-$ $\mathrm{L}_{7}$ and $\mathrm{S}_{1}-\mathrm{S}_{3}$ in the dog (GETTY, 1981), $\mathrm{L}_{4}-\mathrm{L}_{7}$ and
$\mathrm{S}_{1}-\mathrm{S}_{3}$ in the cat (GETTY, 1981), and $\mathrm{L}_{4}-\mathrm{L}_{7}$ and $\mathrm{S}_{1}-\mathrm{S}_{3}$ in the rabbit (MCLAUGHLIN; CHIASSON, 1987); the latter two results are similar to what we observed in the red-rumped agouti.

Once we established the origin of the lumbosacral plexus in red-rumped agoutis, we were able to define which nerves participated in its constitution. The nerve branches that we identified were represented by the lateral femoral cutaneous, genitofemoral, femoral, obturator, sciatic, cranial gluteal, caudal gluteal, and pudendal nerves. This constitution is similar to what has been described for the lowland paca (TONINI et al., 2014), although the authors also suggest involvement of the caudal femoral cutaneous nerve, which was not observed in the red-rumped agouti. In other caviidae, such as the rock cavy (LACERDA et al., 2006) and Spix's yellow-toothed cavy (OLIVEIRA et al., 2014), the genitofemoral and lateral femoral cutaneous nerves do not participate in the formation of this plexus, and this is inconsistent with what we observed in the red-rumped agouti. Anatomy treaties typically refer to the formation of the lumbosacral plexus as a structure that can consist of a variable set of nerves (DYCE et al., 2004; FRANDSON et al., 2005; KÖNIG; LIEBICH, 2011). For instance, Getty (1981) described the lumbosacral plexus as two different components (lumbar and sacral plexuses), and believed their formation to vary in domestic species. In turn, Frandson et al. (2005) have reported that the cranial gluteal, caudal gluteal, femoral, obturator, sciatic, and pudendal nerves belong to the plexus, while Habel and Robert (1986) cited the femoral, obturator, sciatic, and pudendal nerves as participants in the plexus in domestic animals.

In wild animals, few authors have addressed the spinal nerves that make up the plexus; however, some authors have briefly cited their existence and have briefly mentioned the participation of a lumbosacral trunk. In the chinchilla, the lumbosacral plexus consists of the ileum-hypogastric, ileo-inguinal, lateral femoral cutaneous, genitofemoral, obturator, femoral, sciatic, pudendal, and rectal caudal nerves 
(RONDINI et al., 2005). In the fur seal, this plexus is formed by the ileum-hypogastric, ileo-inguinal, lateral femoral cutaneous, genitofemoral, obturator, femoral, sciatic plexus, pudendal, and rectal caudal nerves (CASTRO et al., 2009). On the other hand, the plexus is formed by the femoral, saphenous, obturator, sciatic, tibial, common fibular, cranial gluteal, and caudal gluteal nerves in the ocelot (LOPES et al., 2012). In red-rumped agoutis, we revealed that the lumbosacral plexus consisted of the lateral femoral cutaneous, genitofemoral, femoral, obturator, sciatic, cranial gluteal, caudal gluteal, and pudendal nerves, and that these nerves stemmed from the roots of $\mathrm{L}_{4}-\mathrm{S}_{3}$ (Type I).

Here, we found that the lateral femoral cutaneous nerve in the specimens under study predominantly stemmed from the fourth and fifth lumbar nerves. In the lowland paca (TONINI et al., 2014), $\mathrm{L}_{5}$ is the most frequent nerve root of origin for the lateral femoral cutaneous nerve, while $\mathrm{L}_{5} \mathrm{~L}_{6}$ less frequently contribute to this nerve. On the other hand, the lateral femoral cutaneous nerve originates at $\mathrm{L}_{4}$ in the red squirrel (AYDIN, 2010), which was less frequently found in the red-rumped agouti. Together, these findings suggest that the origin of the lateral femoral cutaneous nerve in other rodents occurs from either $\mathrm{L}_{5}$ or $\mathrm{L}_{4}$, but that both lumbar nerve roots were involved in the origin of the lateral femoral cutaneous nerve in red-rumped agoutis."

Similar to the lateral femoral cutaneous nerve, we found that the genitofemoral nerve in the redrumped agouti stemmed from branches of the fourth and fifth lumbar nerves, but that there was also potential contribution by $\mathrm{L}_{6}$. In the lowland paca (TONINI et al., 2014), this nerve most frequently stems from $\mathrm{L}_{4}$, but can originate from $\mathrm{L}_{4} \mathrm{~L}_{5}$ or only from $\mathrm{L}_{5}$. The latter results were also found in the red-rumped agouti. On the other hand, in the chinchilla (PEREIRA; RICKES, 2011) and porcupine (AYDIN et al., 2009), the genitofemoral nerve has been reported to stem from $\mathrm{L}_{3}$ and $\mathrm{T}_{15}-\mathrm{L}_{1}$, respectively. These roots were not identified in the formation of this nerve in the red-rumped agouti.
In terms of the femoral nerve of the red-rumped agouti, we found that it stemmed more frequently from $\mathrm{L}_{5}-\mathrm{L}_{7}$ or $\mathrm{L}_{5} \mathrm{~L}_{6}$, and this findings is consistent with what has been described in the rock cavy (OLIVEIRA et al., 2011) and in the lowland paca (TONINI et al., 2014). It is noteworthy that, in the lowland paca, the authors also report the origin of the femoral nerve from $\mathrm{L}_{6} \mathrm{~L}_{7}$, a result that was also found less frequently in the red-rumped agouti. In turn, Lacerda et al. (2006) reported that, in the rock cavy, the origin of this nerve occurs at $\mathrm{L}_{6} \mathrm{~L}_{7}$ or $\mathrm{L}_{5}-\mathrm{L}_{7}$ in the presence of the seventh lumbar vertebra and from $\mathrm{L}_{4} \mathrm{~L}_{5}$ when there are only six lumbar vertebrae. In the latter case, the femoral nerve has the possibility of receiving contribution from $\mathrm{L}_{6}$, a combination that was seen in only one red-rumped agouti specimen in the current study and that was restricted to the right antimere. In Spix's yellow-toothed cavy, Oliveira et al. (2014) reported that this nerve mainly stems from $\mathrm{L}_{5} \mathrm{~L}_{6}$, and that it can receive contributions from the fourth or seventh lumbar nerves. These findings were similar to what was found in the red-rumped agouti, with the exception that there was no case where the $\mathrm{L}_{4}$ contributed to the formation of the femoral nerve.

In the red-rumped agouti, we observed that the obturator nerve predominantly stemmed from the union between the $\mathrm{L}_{5}-\mathrm{L}_{7}$ nerves, and less frequently from $\mathrm{L}_{5} \mathrm{~L}_{6}$ or $\mathrm{L}_{6} \mathrm{~L}_{7}$. In pigs the origin of the obturator nerve occurs from $\mathrm{L}_{4}-\mathrm{L}_{6}$ (CHAGAS et al., 2006), in bovines from $\mathrm{L}_{5}-\mathrm{S}_{1}$ (MIRANDA et al., 2007), and in goats from $\mathrm{L}_{5} \mathrm{~L}_{6}$ (NASCIMENTO et al., 2013). In turn, in Spix's yellow-toothed cavy (OLIVEIRA et al., 2014), the obturator nerve is usually found stemming from $\mathrm{L}_{5} \mathrm{~L}_{6}$, and it can receive contributions from $\mathrm{L}_{4}$ or $\mathrm{L}_{7}$. In the lowland paca, the obturator nerve more frequently originates from $\mathrm{L}_{6}$, but it can receive branches from $\mathrm{L}_{5}$ or $\mathrm{L}_{7}$. On the other hand, in the red squirrel (AYDIN, 2010), this nerve is formed from the roots of $\mathrm{L}_{4}-\mathrm{L}_{5}$. Together, these results reveal variations in the origin of the obturator nerve in the lowland paca and the red squirrel when compared to what was found in the red-rumped 
agouti. More specifically, these divergent results only apply to nerve formation from $\mathrm{L}_{6}$ alone, or when $\mathrm{L}_{4}$ is involved.

The sciatic nerve of the red-rumped agouti was found to stem from branches of $\mathrm{L}_{7}, \mathrm{~S}_{1}$, and $\mathrm{S}_{2}$ or $\mathrm{L}_{6}-$ $\mathrm{S}_{2}$, resembling what has been described by Tonini et al. (2014) in the lowland paca and by Lacerda et al. (2006) in the rock cavy, where the authors suggest $\mathrm{L}_{6}-\mathrm{S}_{2}$ origin as a standard model. On the other hand, the sciatic nerve of Spix's yellow-toothed cavy (OLIVEIRA et al., 2010) has been suggested as originating from the ventral roots of $\mathrm{L}_{6} \mathrm{~L}_{7} \mathrm{~S}_{1}$, which differs from what we observed in the current study. It is worth noting that other authors have reported the of origin sciatic nerve in Spix's yellow-toothed cavy as occurring from $\mathrm{L}_{7} \mathrm{~S}_{1} \mathrm{~S}_{2}$, which was observed in most red-rumped agouti specimens investigated here. Finally, the origin of the sciatic nerve in the chinchilla (PEREIRA; RICKES, 2011) $\left(\mathrm{L}_{5} \mathrm{~L}_{6}\right.$ and $\left.\mathrm{S}_{1}\right)$, mouse $\left(\mathrm{L}_{3} \mathrm{~L}_{4}\right)$, and rat $\left(\mathrm{L}_{4} \mathrm{~L}_{5}\right)$ (RIGAUD et al., 2008), all differed from the origin observed in the red-rumped agouti.

In most specimens evaluated here, the gluteal cranial nerve stemmed from L7. This finding is consistent with what has been reported by Lacerda et al. (2006) in some rock cavies, dependent on the number of lumbar vertebrae, and by Oliveira et al. (2014) in the Spix's yellow-toothed cavy. On the other hand, the formation of this nerve component in the porcupine, according to Aydin et al. (2009), stems from $\mathrm{L}_{3}$ and $\mathrm{L}_{4}$ or just $\mathrm{L}_{3}$ branches. Moreover, we observed that the caudal gluteal nerve of the redrumped agouti stemmed more frequently from $S_{1}$ roots, and this has been described in Spix's yellowtoothed cavy by Oliveira et al. (2014) and in the lowland paca by Tonini et al. (2014).

Lastly, we observed that the pudendal nerve of the red-rumped agouti stemmed from the ventral branches of $\mathrm{S}_{2}$ and $\mathrm{S}_{3}$. This finding is consistent with what has been described in rodents, such as chinchillas (RONDINI et al., 2005), rock cavies (LACERDA et al., 2006), Spix's yellow-toothed cavy (OLIVEIRA et al., 2014), and lowland pacas (TONINI et al., 2014), as well as with what has been reported for pigs and domestic carnivores, according to Getty (1981) and Schaller (1999), respectively. Alternatively, the origin of the pudendal nerve of the red-rumped agouti differed from what has been cited by Barros et al. (2003) in studies on primates and in one study on chinchillas by Pereira and Rickes (2011); both groups attribute the origin of the pudendal nerve to $\mathrm{S}_{1} \mathrm{~S}_{2}$. Likewise, considering that the origin of the pudendal nerve in Spix's yellow-toothed cavy (OLIVEIRA et al, 2014) and in rock cavies (LACERDA et al., 2006) has been attributed to the ventral branches of $\mathrm{S}_{2}$ and $\mathrm{S}_{3}$, we found three specimens of the red-rumped agouti where the origin of this nerve was only from $\mathrm{S}_{3}$ and two where this nerve originated from $\mathrm{S}_{3}$ and $\mathrm{S}_{4}$. This latter finding is consistent with what has been reported for the collared anteater (CARDOSO et al., 2013).

\section{Conclusions}

In the current study, we found that the lumbosacral plexus of the red-rumped agouti stemmed from the nerve roots derived from the last four lumbar nerves and the first three sacral nerves or from the last three lumbar nerves and the first three sacral nerves; rare contributions by the fourth sacral nerve were also observed. We further established that the following nerves participated in the constitution of the lumbosacral plexus in red-rumped agoutis: genitofemoral, lateral femoral cutaneous, femoral, obturator, sciatic, cranial gluteal, caudal gluteal, and pudendal nerves. The lumbosacral plexus in the red-rumped agouti was similar to what has been observed in other caviidae rodents, such as the rock cavy, lowland paca, and Spix's yellow-toothed cavy, suggesting a common pattern for this family. These results may provide a basis for conducting clinical and surgical procedures in this species. Moreover, our findings complement the current literature and will be useful in advancing the study of wild rodents. 


\section{References}

AYDIN, A. The spinal nerves that constitute the plexus lumbosacrales of the red squirrel (Sciurus vulgaris). Veterinarni Medicina, Praga, v. 55, n. 4, p. 183-186, 2010.

AYDIN, A.; DINC, G.; YILMAZ, S. The spinal nerves that constitute the plexus lumbosacrales of porcupines (Hystrix cristata). Veterinarni Medicina, Praga, v. 54, n. 4, p. 194-197, 2009.

BARROS, R. A. C.; PRADA, I. L. S.; SILVA, Z.; RIBEIRO, A. R.; SILVA, D. C. O. Constituição do plexo lombar em macaco Cebus apella. Brazilian Journal of Veterinary Research and Animal Science, São Paulo, v. 40, n. 5, p. 373-381, 2003.

CARDOSO, J. R.; SOUZA, P. R.; CRUZ, V. S.; BENETTI, E. J.; BRITO E SILVA, M. S.; MOREIRA, P. C.; CARDOSO, A. A. L.; MARTINS, A. K.; ABREU, T.; SIMÕES, K.; GUIMARÃES, F. R. Estudo anatômico do plexo lombossacral de Tamandua tetradactyla. Arquivo Brasileiro de Medicina Veterinária e Zootecnia, Belo Horizonte, v. 65, n. 6, p. 1720-1728, 2013.

CASTRO, T. F.; SOUZA, D. A. S.; SILVA FILHO, R. P.; PEREIRA, M. A. M. Sistematização da inervação Lombar e sacral em Arctocephalus australis. Brazilian Journal of Veterinary Research and Animal Science, São Paulo, v. 46, n. 5, p. 404-411, 2009.

CHAGAS, R. G.; DRUMMOND, S. S.; SILVA, F. O. C.; EURIDES, D.; ALVES, E. C. M.; MIRANDA, R. L. Origem e distribuição do nervo obturatório em suínos (Sus scrofa domesticus - Linnaeus, 1758) da linhagem AG-1050. Arquivo de ciências veterinárias e zoologia da UNIPAR, Umuarama, v. 9, n. 1, p. 15-20, 2006.

COOPER, G.; SCHILLER, A.L. Anatomy of the guinea pig. Cambridge: Harvard University, 1975. 417 p.

CRUZ, V. S.; CARDOSO, J. R.; ARAÚJO, L. B. M.; SOUZA, P. B.; BORGES, N. C.; ARAÚJO, E. G. Aspectos anatômicos do plexo lombossacral de Myrmecophaga tridactyla (Linnaeus, 1758). Bioscience Journal, Uberlândia, v. 30, n. 1, p. 235-244, 2014.

DYCE, K. M.; SACK, W. O.; WENSING, C. J. G. Tratado de anatomia veterinária. 2. ed. Rio de Janeiro: Guanabara Koogan, 2004.

FANTONI, D. T.; CORTOPASSI, S. R. G. Anestesia em cães e gatos. 2. ed. São Paulo: Roca, 2009. 632 p.

FRANDSON, R. D.; WILKE, W. L.; FAILS, A. D. Anatomia e fisiologia dos animais da fazenda. 6. ed. Rio de Janeiro: Guanabara Koogan, 2005. 454 p.
GETTY, R. Sisson/Grossman: Anatomia dos animais domésticos. 5. ed. Rio de Janeiro: Editora Interamericana, 1981. v. 2, 1986 p.

GREENE, E. C. Anatomy of the rat. New York: American Philosophical Society, 1963. v. 2, 370 p.

HABEL, A. DE LAHUNTA; ROBERTY, W. B. Appliedy veterinaria anatomy. Washington: Saunders Company, 1986.

INTERNATIONAL COMMITTEE ON VETERINARY GROSS ANATOMICAL NOMENCLATURE. Nomina Anatômica Veterinária. 5. ed. Knoxville: World Association on Veterinary Anatomist, 2012. 190 p.

KLEIMAN, D. G.; EISENBERG, J. F.; MALIAK, E. Reproductive parameters and productivity of caviomorph rodents. In: EISENBERG, J. F. (Ed.). Vertebrate ecology in the northern Neotropics. $4^{\text {th }}$ ed. Washington: Smithsonian Institution, 1979. p. 173-183.

KÖNIG, H. E.; LIEBICH, H. G. Anatomia dos Animais domésticos: texto e atlas colorido. 4. ed. Porto Alegre: Artmed, 2011. 788 p.

LACERDA, P. M. O.; MOURA, C. E. B.; MIGLINO, M. A.; OLIVEIRA, M. F.; ALBUQUERQUE, J. F. G. Origem do plexo lombossacral de mocó (Kerondo rupestris). Brazilian Journal of Veterinary Research and Animal Science, São Paulo, v. 43, n. 5, p. 620-628, 2006.

LOPES, J. A.; FÉ, L. C. M.; LIMA, A. R.; PEREIRA, L. C.; BRANCO, E. Morfologia do plexo lombossacral da jaguatirica (Leopardus pardalis). Biotemas, Florianópolis, v. 25, n. 4, p. 215-220, 2012.

MASSONE, F. Anestesiologia veterinária: farmacologia e técnicas. 6. ed. Rio de Janeiro: Guanabara Koogan, 2011. $448 \mathrm{p}$.

MCLAUGHLIN, C. A.; CHIASSON, R. B. Laboratory anatomy of the rabbit. W.C. Iowa: Brown Company, $1987.68 \mathrm{p}$.

MIRANDA, R. L.; CARNEIRO E SILVA, F. O.; SEVERINO, R. S.; DRUMMOND, S. S.; GONÇALVEZ, R. C. Origens e distribuições dos nervos obturatórios em fetos fêmeas de bovinos azebuados. Bioscience Jounal, Uberlândia, v. 23, n. 4, p. 120-127, 2007.

MOCKRIN, M. H.; BENNET, E. L.; LABRUNA, D. T. Wildlife farming: a viable alternative to hunting in tropical forests? New York: Wildlife Conservation Society. WCS Working Paper No. 23, 2005. 32 p.

MOOJEN, J. Os roedores do Brasil. Rio de Janeiro: Instituto Nacional do Livro, 1952. 214 p. 
NASCIMENTO, R. M.; ESTRUC, T. M.; PEREIRA, J. L. A.; SCHERER, P. O.; FIGUEIREDO, M. A. Origem e distribuição antimérica dos nervos obturatórios em caprinos neonatos da raça Saanen. Revista Brasileira de Ciência Veterinária, Niterói, v. 20, n. 2, p. 74-79, 2013.

OLIVEIRA, G. B.; ALBUQUERQUE, J. F. G.; RODRIGUES, M. N.; PAIVA, A. L. C.; MOURA, C. E. B.; MIGLINO, M. A.; OLIVEIRA, M. F. Origem e distribuição do nervo femoral do mocó, Kerodon rupestris (Caviidae). Pesquisa Veterinária Brasileira, Seropédica, v. 31. n. 1, p. 84-88, 2011.

OLIVEIRA, G. B.; RODRIGUES, M. N.; SOUSA, E. S.; PAIVA, A. L. C.; MOURA, C. E. B.; MIGLINO, M. A.; OLIVEIRA, M. F. Origem e distribuição dos nervos isquiáticos do preá. Ciência Rural, Santa Maria, v. 40, n. 8, p. 1741-1745, 2010.

OLIVEIRA, G. B.; RODRIGUES, M. N.; SOUSA, R. S.; MOURA, C. E. B.; MIGLINO, M. A.; OLIVEIRA, M. F. Origin of the lumbosacral plexus in Galea spixii (Wagler, 1831) (Rodentia, Caviidae). Biotemas, Florianópolis, v. 27, n. 4, p. 107-115, 2014.

PEREIRA, M. A. M.; RICKES, E. M. The spinal nerves that constitute the lumbosacral plexus and their distribution in the chinchilla. Journal of the South African Veterinary Association, Pretoria, v. 82, n. 3, p. 150-154, 2011.
RIGAUD, M.; GEMES, G.; BARABAS, M. E.; CHERNOFF, D. I.; ABRAMA, S. E.; STUCKY, C. L.; HOGANA, Q. H. Species and strain differences in rodent sciatic nerve anatomy: Implications for studies of neuropathic pain. Pain, Amsterdam, v. 136, n. 1-2, p. 188-201, 2008.

RONDINI, B. T.; GAMBA, C. O.; PEREIRA, R. L.; WULFF, M. L.; PEREIRA, M. A. M.; RICKES, E. M. Sistematização dos territórios nervosos do plexo lombo-sacral em Chinchilla lanigera. In: SALÃO DE INICIAÇÃO CIENTÍFICA, 17., 2005, Porto Alegre. Anais... Porto Alegre: UFRGS, 2005. p. 401.

SANTOS, R. C.; AlBUQUERQUE, J. F. G.; SILVA, M. C. V.; MOURA, C. E. B.; CHAGAS, R. S. N.; BARBOSA, R. R.; MIGLINO, M. A. Anatomia do nervo isquiático em mocós (Kerodon rupestris WIED, 1820) aplicada a clínica de animais silvestres. Brazilian Journal of Veterinary Research and Animal Science, São Paulo, v. 43, n. 5, p. 647-653, 2006.

SCHALLER, O. Nomenclatura anatômica veterinária ilustrada. São Paulo: Manole, 1999. 575 p.

TONINI, M. G. O.; SASAHARA, T. H. C.; LEAL, L. M.; MACHADO, M. R. F. Origem e distribuição do plexo lombossacral da paca (Cuniculus paca, Linnaeus 1766). Biotemas, Florianópolis, v. 27, n. 2, p. 157-162, 2014. 
